\title{
Conceptualizing Zakat Institutions within the Framework of Hybrid Organizations
}

\author{
Vita Arumsari \\ Politeknik Negeri Semarang \\ Muhamad Rizky Rizaldy \\ Universitas Gunadarma \\ Putri Syifa Amalia \\ Institut Tazkia
}

Paper to be presented at the $4^{\text {th }}$ International Conference of Zakat (ICONZ)

7-8 October 2020, Surabaya, Indonesia

\begin{abstract}
Historically, zakah institution was only run by the state, which was indeed managed under the state or public logic. On the other hand, we are now in the era of 'civic society', where the 'bureaucratic decline' emphasized the incapability of the state to be an efficient actor of development (Bawole, Ibrahim, Hossain, \& Mensah, 2017; Hirschmann, 1999). The role of non-state actors is increasingly important to be the better development engines.

The fact as mentioned earlier has put these non-state actors of development, including zakah institutions, in a dilemma between two institutional logics: market or commercial logic and public or social logics (Schröer \& Jäger, 2015). These institutions must face distinct problems which do not occur in a conventional single-logic organization. They regularly need to deal with the conflict between two logics, financial or social logics.

This study aims to conceptualize a further argument that zakah institutions are hybrid institutions, and therefore, a list of lessons could be explored. Systematic Literature Review (SLR) is being applied for obtaining facts and related cases to this study.

Few recommendations to sustain the zakah institutional growth are found. Regarding its organizational legacy (Furusten \& Junker, 2019), a good communication method to the society will result in the sustainable institutional "business" as a form of "promotion". According to Battilana (2018), setting organizational goals, structuring organizational activities, selecting organizational members, and socializing organizational members might be able to keep the institution in the hybridity track. Further, instead of creating "entrepreneurship for social value creation", the better concept is "social value for entrepreneurship" (Arogyaswamy, 2017).
\end{abstract}

Keywords: zakah institution, hybrid organization, Islamic social finance

\section{INTRODUCTION}

Hybrid organizations, which are dealing with multiple identities and goals, reaching economics and social goals at the same time (Battilana \& Lee, 2014; Ebrahim, Battilana, \& Mair, 2014; Jay, 2013; Mersland, Nyarko, \& Sirisena, 2020; Santos, Pache, \&
Birkholz, 2015; Tracey, Phillips, \& Jarvis, 2011), need more understanding of the situation hence it reaches the highest performance of social and economic goals among circumstances which tend to fail it (Ebrahim et al., 2014). 
In the sense of saving the community, a hybrid is the identity of an organization which able to merge the civil society and market while involving a solidarity exchange in a communal area both for financial and non-financial resources. Further, it also involves market value calculation in the sense of communal solidarity as an exchange of financial and non-financial resources. Hybrid organization creates "functional solidarity" where it underlies the non-distribution constraint for strategically calculated exchanges of the leverage on social matters for market resources (Jäger \& Schröer, 2014).

Zakah, on the other hand is a charity organization which collect fund as part of religious duty of the believers in Islam. Zakah is mentioned as ethico-economic institution which delivering the fund collected for alleviating poverty and it reaches grass root level on point. Align with Sadeq (1996) suggested in the paper, we aim to generate money from zakah fund collected hence it will last longer and sustain as it keeps on generating income which in the end use to eradicate poverty on grass root level (Sadeq, 1996) by distribute it to the eight asnaf.

\section{LITERATURE REVIEW}

It has been widely known in modern society the presence of hybridity despite the fact of its contradictory principle applied (Pache \& Santos, 2013). On the other hand, Islamic financial institutions has a role in boosting a sound growth, enlarge financial inclusivity, intermediation, as well as lessen the risks the poor might receive and the vulnerability, further, support the financial stability and development by combining the contradictory purpose (Ahmed, Mohieldin, Verbeek, \& Aboulmagd, 2015).

Noticing the development of Islamic financial institutions, it has become a second-best solution as the result of its inability of fulfilling the framework of Islamic economic system. An institutional solution might be a way out of this situation by focussing on micro dynamics of the society. In this case, zakah institutions able to provide it, both economically and socially in a voluntary form as this is mandatory in Islam for the believer. Zakah institutions have been an intermediary institution to do income distribution of Islamic social fund to the poor. Hence, rather than giving the money at once, it is much better to maximize the collected fund by generate it by establishing projects (Asutay, 2007; Sadeq, 1996). This has been well known as an alternative economy (Asutay, 2007).

Just like social enterprises which are an organization living by generating income through commercial economics activities. Comparing to traditional not-forprofit organization, by resource, it is different as the resource coming from a mere donations (Battilana, 2018a). Looking up to zakah organization which are currently focus as intermediary institutions, the duties are accepting donation and delivering to the needy, it means zakah organizations belong to traditional not-forprofit organization.

Process of hybridizations, both happen in commercial and social companies. The non-profit organizations doing effort in generating income for the sake of compensating their donors or subsidy they received, hence they will not take it for granted, although in the end it will trigger resistance because of the divergent change. By taking a closer look, in corporation, hybrid is more about injecting social value within the economic sector, whilst on the non-profit organizations, hybrid is more about inserting the economic value within the social sphere. The scope is no longer about how far the hybrid system to bring more impacts to the companies but wider society to tackle inequality problems as well 
cultural gap happen within (Battilana, 2018a).

\section{METHODOLOGY}

Systematic Literature Review (SLR) is being applied for obtaining facts and related cases to this study. Through this system we discover related sources to substantiate the role of zakah institutions both in pursuing social and commercial purpose, as hybrid organizations. Hence, it able to escalate the institutional sustainability for broader impacts received by the wider society. Further, by implementing SLR, it is expected to find ways for zakah institutions to adopt lesson learnt by other organizations to sustain the hybridity in the long run.

\section{RESULTS AND DISCUSSION}

\section{The Need of Clearer Identity}

It is understandable for having multiple logics within an organisation even though overcoming the new hybridity logics in an organization might be intricate. The process of building it involves the background of the founder (Battilana \& Dorado, 2010).

Identity addresses the sense of belonging within a group of individuals regarding their inclusiveness within an organization (Ashforth \& Mael, 1989) where it leads to overcome the complexity (Greenwood, Raynard, Kodeih, Micelotta, \& Lounsbury, 2011). In advance, it will create distinctive value to make individuals proud of the value they are holding within organization value, thus it leads individuals to act align with the organizational identity which result in strengthening the organizational value (Ashforth \& Mael, 1989).

The mission is reflected through its identity as it concerns the organization's nexus, distinctive, and enduring character (Ashforth \& Mael, 1996). Realize it or not, individual's contentment reflects in the organization effectiveness in day-to-day activities (Ashforth \& Mael, 1989).

Applying a sound organizational identity to make sure the sustainability of the logics stable in the long run can be started in the early step of hiring and socializing phase. Meanwhile, organizations should be careful because when a hybrid organization have multiple identity to be acknowledged, there is a tendency for hybrid organizations to have an ideographic organizational identity. Implementing the tabula-rasa approach, used by Los Andes, might be extremely useful as it will indirectly ignore the institutional environment and forming a "new" character for the potential employees. This condition leads to a hampered development of a new hybrid organization as it is not in a form of one big entity, instead, they see it separate entity inside. In the end, focusing on the socialization approach, which specifically focused on hires' attention on the excellency of operation, will be more effective in forming balance among the combined logics (Battilana \& Dorado, 2010).

Hybrid creates practical solidarity where society able (Jager \& Schroer, 2014) and embrace (Jay, 2013) it together. It has been known that pursuing financial and social goals at the same time as the value of pursuing financial goal is more salient than social goal (Battilana, 2018b).

Hybrid organisation is not hybrid when they cannot balance between the economics and social value. In term of the organizations performance, one of the problem to be avoided by the hybrid organisations are the drift, even so, it can be managed by keeping track on the financial and social achievements and immediately making improvement whenever it is seen fit to prevent drift (Battilana, 2018a). The tendency of mission drift is highly likely to happen without the balance (Battilana, 2018a). It has become one of the concerns 
for many observers upon the sustainability of hybrid organizations (Battilana \& Dorado, 2010).

By doing this, zakah organizations performance can be managed and improved better, compared to the current business system, if there is a tight monitor and fix immediately whenever there is something wrong. Some of the lessons learnt from B Corps, they apply certification every two years to evaluate on employees, customers, suppliers, community, and the environment, particularly for environment they measure their willingness to encounter periodic independent audits (Battilana, 2018a). In zakah organizations, concerning to the environment, the officers can directly go to the field to see whether the fund channelled is beneficial in client's life as well as used for crucial things.

Surprisingly, the fears rise among the funders who thrive for hybrid organizations' balance lifestyle, for the sake of pursuing the economic value. In fact, it is likely not to happen within zakah organizations as per status quo, those who already given their money to the zakah organization do not expect the money back as it is part of religious obligation. Though in fact, it is needed to give the best performance to the society as a proof that amanah has been well-delivered to the appointed groups.

\section{Internal Needs}

Hybrid organizations' identity includes the members' identity on the organizations, the structure of organizations, as well as the members' actions which able to unity market and society (Jager \& Schroer, 2014).

Founders, organizational culture, and partners reflect the way company recruit their employees. Culture has been successfully create "family" feeling, as a result it keeps the organization running balance, both in social and economics purposes (Greinert \& Levinsohn, 2016).
The importance of mission and value shape the shared identities between social and economics identity, hence members able to articulate it into vision while having personal views (Ismail \& Johnson, 2019).

Creating organization culture, one of the ways is by considering the leader's background. Those who are already exposed to the hybrid organisations, both direct by doing the business straight-away and indirect by being exposed through their parents' business, are likely to establish hybrid organisations (Lee \& Battilana, 2013).

Organizational identity is first introduced to the employee candidate on the hiring and socialization phase, this will result in a more sustainable organization (Battilana \& Dorado, 2010) as people has been acknowledged of the company in the beginning and they are given chance either to "take it" or "leave it".

Hybrid can be one of myriad ways to provide employees the working meaning (Battilana, 2018a). Eliminating the mismatch between the institutional goals and organizational types. When the goals pursued are both social and financial goals, hence the organizational types is tailored to cater both of the goals (Battilana, 2018a).

The tension emerges from internal and external pressures. Internal pressures come up in relation among members regarding the discrepancies on who choose what regarding the financial purpose and the social ones. From the external pressure, it starts when the organization cannot fulfil the funders' expectation in term of economics and social legitimacy which might generate internal tensions about resource and skill allocations (Battilana, 2018a).

In fact, in zakat organization, as it is mandatory for religious purpose, what people expects is the utilization of the fund. In the first place, there is no demand that the 
zakah organization should generate money in return of their zakah payment.

\section{Establishing Organizational Governance}

Establishing a suitable organizational governance is highly suggested thus organizations do not need to be sacrificing its missions as both are completing rather than against each other. There are two cores of governance's roles, sustaining social and economic activities while sustaining the agents' performance. First, making the progress, both for social and economic activities, measurable is the most important thing to do. On a side note, it is easier, indeed, to measure the economics progress to compare it from one institution to another (Castellas, Stubbs, \& Ambrosini, 2019). Even though in zakah organizations the fund is voluntarily collected from Muslim believer as part of religious duty, still, to sustain and give more benefits as there are many aspects to be funded within Muslim communities, zakah organisations better to want the fund to sustain by doing business.

On the other hand, measuring the social purposes is immeasurable (Castellas et al., 2019), remembering that each institution has different goals which affected by various actors and environmental variables. Second, sustaining the agents' performance is executed by monitoring the performance of the staff, in term of delivering social and economic goals, as well as the outcomes, which is tricky. If output is within the scope of the organization, outcome is the result beyond the scope of the organization (Ebrahim et al., 2014).

After all, the ability to speak the same language with the mustahik and muzakki is crucial to delivering the value for evolving the organisation. As the goal is to bring people from diverse culture and social class to be maximal in receiving the benefit by understanding their background (Greinert \& Levinsohn, 2016). By doing this, it is not merely the money which are sustain but also the benefit received by the recipient when the zakah organisation able to locate what is truly needed by using the language of understanding.

\section{A Process Model of Organizational Responses}

Hybrid organisations need to get through sequence of separating, negotiating, aggregating, and subjectively assessing the value created in coping with several challenges, namely the unequal weight of priority upon organisations goals, immeasurability of the social goals compared to the economics goal, interconnection of values, and value collection issues as decision at one unit able to give different impact on aggregate level which known as cognitive dissonance, incommensurability, interdependence, and aggregation respectively (Castellas et al., 2019).

Separate means that hybrid organisations as having pluralism goals need to be decoupling their goals one by one and see it from monism perspective. Further, it has been understood that one goal is connected to the other one and focusing each one is a trade-off if the focus on one of the goals unequally, hence negotiation is needed by setting a benchmark of maximum and minimum limit. Setting benchmark within pluralism means that organisations will not do a tradeoff as every need fulfilled, for instance financial and social goals. On the next level, those pluralism need to see the value aggregately and how far it already impacts. Subsequently, assessing is needed in "negotiate" step to see the swap value.

\section{About Accountability Challenges}

Unlike other hybrid organisations, zakah organisations involves amazingly a lot of muslims stakeholders who voluntarily submitting their money to the zakah organisations. Usually people will monitor it through the report about where the money goes, but by generating the money through business, this might lead people to even 
scrutinize the usage of their money as the number might quadruple if the business is good, despite the fact that zakah organisations need to allocate money for operational fee.

Muzakki (zakah payer) loyalty to a zakah organisation hinges on how the zakah organisation deliver the zakah collected to the right individual target or community services (include to the eight asnaf for zakah fitrah payment and for social activities for zakah maal). They might have tendency to shift to the other zakah organisation if their expectation of having their money delivered to the targeted community ignored which lead the organisation to bear reputational risk and it might be contagious to other zakah organisation. The impact can be worse if the organisation is governmental based which have everything decentralized.

By using the business model canvas of Bocken et.al (2014) in Davies and Doherty (2019), there is a possibility to predict the possible source of tensions.

According to Davies and Doherty (2019), where they have done longitudinal study with Cafedirect, organisations should have avoiding unimportant tensions by not using implicit message. This might affecting the commercial value whilst in fact customers who are aware with ethical value suffice the implicit message (Davies \& Doherty, 2019). On a side note, we cannot neglect the important of organisational branding.

Further by applying contingent value spill over and choosing the right partner who fully comprehend value capture the weight of the organisations will be lighter. It cannot be neglected that managing triple-bottom-line business model is not simple. Hence, there is separate team who focus on sustaining societal value capture (governance team) and who focus on sustaining commercial value capture (business team). It has been argued that establishing one integrated business model for hybrid organisations is possible to eradicate the tensions within (Davies \& Doherty, 2019). By creating different team for different mission, it will eliminate the negative impact of the possible fault lines happen within organizations (Crucke \& Knockaert, 2016).

\section{About Business Model}

The main challenge of the organisation is to sustain the innovation while being aware of the plurality of keeping social and financial mission soaring high. It is normal that everyone being excited when the concept is new, even so as the time goes by people hunger for something new. Greenpop realized the thing that make people linger with it, value. Hence, it leads them to focus on value preposition, focus on the area where it intertwines with field they are associated (Greinert \& Levinsohn, 2016).

Innovation as the key of the business to keep running and provide more benefit to people. Even when the financial source is stable as it is coming from the obligatory fund collection, zakah organisations need to be hybrid to keep the fund sustain hence it has wider outreach and more people are having better safety net and can live prosper, whether it is in a form of having proper education by receiving financial help from the zakah organisation or having proper health facility hence it reduces the sick people, which might have the possibility of contagion the virus. In other words, zakah organisation as the preventive circle of worst situation that might happen in the future if it was not taken care sufficiently.

\section{Maintaining the Hybridity (Problems arise)}

There are several researches delivering ways to keep the hybridity sustain through the ups and downs. Four pillars have been prepared as followed by (Battilana, 2018b):

\section{a. Setting organizational goals}


Create financial and social goals to pursue.

b. Structuring organizational activities Combining the social and economic activities, make it separate, or by doing combination and differentiation of two goals at the same time based on the needs.

c. Selecting organizational members Choosing individuals who are ready to empty the glass and learn something new or individuals who are already good in hybridity

d. Socializing organizational members Creating the similar understanding among members by establishing training together, give appreciation to those who are excel in certain tasks, and allowing informal interactions among members across different division.

Intrinsic and extrinsic motivational factors has been identified (Caringal-Go \& Hechanova, 2018). Intrinsically, social enterprise workers' loyalty is highly depending on the meaningfulness they perceived. It has been believed that workers experience less stress physically, mentally, and emotionally by having meaningfulness. Also, having a good network of employees for one to another can strengthen the motivation. They need to feel empowered.

Organizational members should not expect of having no conflict and getting used to the uncertainty happen within hybrid organisations (Ismail \& Johnson, 2019). Organizational actors need to constantly translate the problems and find the way out (Jay, 2013).

in MENA, the way to tackle pluralism are by the presence of the existence of trust among beneficiaries and institutions, moral legitimacy, and leaders' role of involvement (Ismail \& Johnson, 2019). Value within hybrid organization lead people go to the same direction together, no matter what background do they have by apply it from the very start on the hiring process or by instil it in the orientation phase. It helps whenever organizations face a dead-end. An organization even choose their employee based on the personalities rather than the technical skills. Even in a team, setting a good example is needed as there is a possibility that teams only weighted on certain purposes while neglecting the other. As leaders, they need to set good example because value transferred through action. Having an one-on-one communication also keep the tension at the minimum level, if not eliminate it (Ismail \& Johnson, 2019). This is one of myriad ways to keep the transparency, as a preventive actions of mission drift (Klein, Schneider, \& Spieth, 2020), and relationship among beneficiaries as well as the partners, hence trust is formed.

\section{CONCLUSION}

Islamic finance institutions are expected to achieve multi-dimensional purposes, including its social impacts along with other purposes. The different nature of organisation it brings led to a different management framework as they start from different values and aims for different objectives. Further, a management guideline, beyond financial and legal aspects need to be established, especially regarding the talent selection criteria of leadership, government/authorities could play the major role on this. All in all, in managerial level, leaders have to embrace the nature of zakah institutions they lead as a hybrid organizations, therefore, they would be able to tailor the culture, talent management, and other operational aspects of their organizations.

\section{REFERENCES}

Ahmed, H., Mohieldin, M., Verbeek, J., \& Aboulmagd, F. (2015). On the Sustainable Development Goals and 
the Role of Islamic Finance. The Policy Research Working Paper Series, (May). https://doi.org/10.1596/1813-94507266

Arogyaswamy, B. (2017). Social entrepreneurship performance measurement: A time-based organizing framework. Business Horizons, 60, 603-611. https://doi.org/10.1016/j.bushor.2017 .05 .004

Ascarya. (2018). Micro Level Models of Integrated Islamic Commercial and Social Finance in Indonesia. In WAIM-UniKL International Conference on Islamic Management (pp. 1-14). Kuala Lumpur: WAIMUniKL.

Ashforth, B. E., \& Mael, F. (1989). Social Identity Theory and the Organization. The Academy of Management Review, 14(1), 20-39. https://doi.org/10.1097/EDE.ObO13 e31812e5535

Ashforth, B. E., \& Mael, F. A. (1996). Organizational Identity and Strategy as a Context for the Individual. Advances in Strategic Management, 13, 19-64.

Asutay, M. (2007). A Political Economy Approach to Islamic Economics: Systemic Understanding for an Alternative Economic System. Kyoto Bulletin of Islamic Area Studies, 1(2), 3-18.

Battilana, J. (2018a). Cracking the organizational challenge of pursuing joint social and financial goals: Social enterprise as a laboratory to understand hybrid organizing. Management (France), 21(4), 12781305.

Battilana, J. (2018b). Cracking the organizational challenge of pursuing joint social and financial goals: Social enterprise as a laboratory to understand hybrid organizing. Management (France), 21(4), 12781305.

https://doi.org/10.3917/mana.214.12 78

Battilana, J., \& Dorado, S. (2010). Building Sustainable Hybrid Organizations: the Case of Commercial Microfinance Organization. The Academy of Management Journal, 53(6), 1419-1440. https://doi.org/10.5465/AMJ.2010.57 318391

Battilana, J., \& Lee, M. (2014). Advancing Research on Hybrid Organizing Insights from the Study of Social Enterprises. Academy of Management Annals, 8(1), 397-441. https://doi.org/10.1080/19416520.20 14.893615

Bawole, J. N., Ibrahim, M., Hossain, F., \& Mensah, J. K. (2017). Development Management in the Developing World: Past Pathways and Future Trajectories. In J. N. Bawole, F. Hossain, A. K. Ghalib, C. J. Rees, \& A. Mamman (Eds.), Development Management: Theory and Practice (pp. 23-35). Routledge.

Besharov, M. L., \& Smith, W. K. (2014). Multiple institutional logics in organizations: Explaining their varied nature and implications. Academy of Management Review, 39(3), 364381.

https://doi.org/10.5465/amr.2011.04 31

Caringal-Go, J. F., \& Hechanova, M. R. M. (2018). Motivational Needs and Intent to Stay of Social Enterprise Workers. Journal of Social Entrepreneurship, 9(3), 200-214. https://doi.org/10.1080/19420676.20 18.1468352

Castellas, E. I., Stubbs, W., \& Ambrosini, V. (2019). Responding to Value Pluralism in Hybrid Organizations. 
Journal of Business Ethics, 159(3), 635-650.

https://doi.org/10.1007/s10551-0183809-2

Crucke, S., \& Knockaert, M. (2016). When Stakeholder Representation Leads to Faultlines: A Study of Board Service Performance in Social Enterprises. Journal of Management Studies, 53(5), 768-793. https://doi.org/10.1111/joms.12197

Davies, I. A., \& Doherty, B. (2019). Balancing a Hybrid Business Model: The Search for Equilibrium at Cafédirect. Journal of Business Ethics, 157(4), 1043-1066. https://doi.org/10.1007/s10551-0183960-9

Ebrahim, A., Battilana, J., \& Mair, J. (2014). The governance of social enterprises: Mission drift and accountability challenges in hybrid organizations $\S$. Research in Organizational Behavior, 34, 81100.

https://doi.org/10.1016/j.riob.2014.0 9.001

Furusten, S., \& Junker, S.-O. (2019). Variations and Dynamics of Hybridity in Different Types of Hybrid Organizations. In Managing Hybrid Organizations Governance, Professionalism and Regulation (pp. 27-48).

Greenwood, R., Raynard, M., Kodeih, F., Micelotta, E. R., \& Lounsbury, M. (2011). Institutional Complexity and Organizational Responses. The Academy of Management Annals, 5(1), 317-371. https://doi.org/10.1080/19416520.20 11.590299

Greinert, A., \& Levinsohn, D. (2016). Entrepreneurship and SME Management Across Africa. https://doi.org/10.1007/978-981-101727-8
Hirschmann, D. (1999). Development management versus third world bureaucracies: A brief history of conflicting interests. Development and Change, 30(2), 287-305. https://doi.org/10.1111/14677660.00118

Ismail, A., \& Johnson, B. (2019). Managing Organizational Paradoxes in Social Enterprises: Case Studies from the MENA Region. Voluntas, 30(3), 516-534.

https://doi.org/10.1007/s11266-01800083-3

Jager, U. P., \& Schroer, A. (2014). Integrated Organizational Identity : A Definition of Hybrid Organizations and a Research Agenda. International Journal of Voluntary and Nonprofit Organizations, 25(5), 1281-1306.

Jäger, U. P., \& Schröer, A. (2014). Integrated Organizational Identity: A Definition of Hybrid Organizations and a Research Agenda. Voluntas, 25(5), 1281-1306. https://doi.org/10.1007/s11266-0139386-1

Jay, J. (2013). Navigating paradox as a mechanism of change and innovation in hybrid organizations. Academy of Management Journal, 56(1), 137159.

https://doi.org/10.5465/amj.2010.077 2

Klein, S., Schneider, S., \& Spieth, P. (2020). How to stay on the road? A business model perspective on mission drift in social purpose organizations. Journal of Business Research, (February 2019), 0-1. https://doi.org/10.1016/j.jbusres.202 0.01 .053

Lee, M., \& Battilana, J. (2013). How the Zebra Got its Stripes: Imprinting of Individuals and Hybrid Social Ventures. Harvard Business School Working Paper, (14-005). 
https://doi.org/10.2139/ssrn.2291686

Mersland, R., Nyarko, S. A., \& Sirisena, A. B. (2020). A hybrid approach to international market selection: The case of impact investing organizations. International Business Review, 29(1), 101624. https://doi.org/10.1016/j.ibusrev.201 9.101624

Pache, A. C., \& Santos, F. (2013). Inside the hybrid organization: Selective coupling as a response to competing institutional logics. Academy of Management Journal, 56(4), 9721001.

https://doi.org/10.5465/amj.2011.040 5

Sadeq, A. M. (1996). Ethico-Economic Institution of Zakah: An Instrument of Self-Reliance and Sustainable Grassroot Development. Humanomics, 12(2), 47-69. https://doi.org/10.1108/eb018775

Santos, F. M., Pache, A.-C., \& Birkholz, C. (2015). Making Hybrids Work: Aligning Business Models and Organizational Design for Social Entreprises. California Management Review, 57(3), 36-59. https://doi.org/10.1525/cmr.2015.57. 3.36

Schröer, A., \& Jäger, U. (2015). Beyond balancing?: A research agenda on leadership in hybrid organizations. International Review of Public Administration, 45(3), 259-281. https://doi.org/10.1080/00208825.20 15.1006032

Tracey, P., Phillips, N., \& Jarvis, O. (2011). Bridging institutional entrepreneurship and the creation of new organizational forms: A multilevel model. Organization Science, 22(1), 60-80. https://doi.org/10.1287/orsc.1090.05
Vita Arumsari

Politeknik Negeri Semarang

vita.arumsari@hotmail.com

Muhamad Rizky Rizaldy

Universitas Gunadarma

rizaldy.sef@gmail.com

Putri Syifa Amalia

Institut Tazkia

syifa.amalia@tazkia.ac.id 